\title{
Developing Image Reading Skills to Support Visual Learning for Children with Learning Disabilities
}

\author{
Magda M. Saleh \\ Faculty of Early Childhood Education, Alexandria University, Egypt \\ magda.mahmoud@alexu.edu.eg \\ Marwa I. Battisha \\ Educational Researcher, PhD from Faculty of Education for Early Childhood \\ marwa.battisha1@gmail.com
}

\begin{abstract}
A training activity is adapted to learn the child with learning difficulties how to read an image in the right way, which in turn develops his visual learning. Two groups are adopted: ten children with learning difficulties as a control group, and ten others as an experimental group, on which the authors have applied specialized-training activities for learning children with learning difficulties on reading images. A test has been applied to evaluate the visual learning of children who have learning difficulties on both the control and experimental groups. It has been shown that there are statistically significant differences for the favor of the experimental group among the average ranks of the control groups scores.
\end{abstract}

Keywords. Training activity, Reading images, Learning disabilities

\section{Introduction}

The awareness of our young children begins with the words, pictures and symbols attached to them since the first year of a child's life. He is fully aware that these images and words carry a clear and meaningful message to him, as they reach him and connect him to his outside world (Manning, 2004). So, we need to learn visual learning skills in education and even teach our students these skills, so that they can read the visual means of reading correctly and use them in the educational process successfully (Williams, 2003). Visual learning requires thinking arising from what we see; it is a non-verbal thinking pattern. It depends on what the eye sees and what is sent from a bar of information that happens (seeing) to the brain, where it is translated, processed and stored in memory for later processing by the mind (Ware, 2008) and (Callow, 2004).

Studies such as (Sword, 2005) have shown that visual learning depends on vision and analysis. It requires the formation of mental images produced by the individual, which is known as visual perception, it means transforming the real image into a value at the level of imagination and the emergence of ideas into outer existence, in a simultaneous work between mental or mental cognition with visual perception. For example, the Internet and the computer have become an important means of thinking which depends on the image first and then move to the written texts. 
The category of people with learning disabilities is one of the most special education classes, attracting the attention of many scientists and researchers in all fields. This is a reflection of the seriousness of this group, which represents a large section of all classes of special education. Ottino (2011) and Bedoin \& Scelles, (2015) pointed out that this category is lost or stray category in the field of kindergartens, as they are not discovered in our kindergarten classes, which prevents the provision of care suits with the educational difficulty suffered by these children. Those children need a multiplier effort from programs and activities to reduce these difficulties, on the one hand, and to provide them with appropriate care and develop their skills on the other hand.

Sword, (2005), Moljord (2018), summarized some of the characteristics of children with learning disabilities as: attention dispersion, slow growth in motor skills memory troubles, problems with reading, writing, arithmetic, and others.

Visual portal activities contribute to the building and strengthening of concepts for these children, where it is difficult for them to understand concepts verbally. Visual support enables them to form a mental image of things, information and attitudes surrounding them that are easier for them to perceive visually and verbally. It also helps to strengthen the communication skills between them and their friends and teacher.

Based on the above, and with the suffering of children in Egypt, there is a clear deficiency in the development of visual learning for children with learning disabilities, which makes it very hard for them to collect and connect with life. This has led the authors to design a variety of activities based on training them on reading skills the correct reading, which affects the development and support of the skills and experiences of learning and helps them to integrate naturally in life.

\section{Literature Review}

Schickedanz (2003) pointed out that the supply of preschools with a large number of printed and visual materials directed towards learning gives a greater idea to these children to understand the learning process and the tendency towards it and to increase children's motivation towards it with look, eye and brain. Also, (Callow, 2004) emphasized the association of vision with reflection, thinking and outlook. Any subject that a person sees happens to pass from the eye to the retina, and then the reflection of the image occurs to him, through the use of thinking. Furthermore, (Moran \& Tegano, 2005) also emphasized the need to focus on image reading experiences and encourage children to draw information and ideas in the picture in order to train them to conclude and interpret represented information visually.

In their study, (Lecas et al, 2011) and (Mcleann \& Gorman, 2006) explained the importance of visual perception for children, which helps them acquire many concepts and develop their thinking during early childhood. The image plays a key role in shaping the child's awareness, as his thinking is linked to the visual learning, trying to understand the world through the language of form and image, which is associated with the imagination that helps the child to pass the limits of immediate reality and calls his past to support the present and the future. This indicates the importance of the image for the individual. Moreover, (McCandliss, 2012), Matthew (2016) concluded that visual learning is one of the most important ways to teach children, because it is a favorite entrance to the souls of children, it teaches them simply and easily how to think, how to acquire knowledge and how to communicate with others.

Also, Ganz \& Flores (2008) examined a set of factors and variables involved in the process of image reading that included a mental process that required decoding the message to the meaning. These factors are: Identify, description or translation then the level of analysis or 
interpretation until it ends with the level of coding or calendar. Both and McCandliss (2012), (Gurny, 2003) noted that visual learning skills are: the skill of recognition of the visual form, the skill of analysis of visual form to parts, the skill of interpretation of visual form and the skill of drawing meaning.

In the present paper, the authors adopted the above mentioned four levels of skills in reading the picture to suit the nature of the sample of this study.

\section{Statement of the Problem}

As the categories of children with learning disabilities in Egypt are not discovered within the classes, which prevents the provision of care the suits with the difficulty from which they suffer, they need a multiplied effort to reduce these difficulties on the one hand, and to provide them with appropriate care and develop their skills on the other.

According to the WHO report, every 100 children, including 8 children with learning difficulties, are unknown and treated as normal children within our society. The above is evidence of the volume of the problem, especially within our schools in Egypt, where the percentage increased in recent years significantly. This encouraged the authors to do this study as a partial attempt to solve this problem by developing the skills of visual education for these children - the study sample - which was confirmed by many of the studies mentioned in the current study in order to support the educational experiences of these children, and to reach them to a level of education that qualifies them to live within the Egyptian society normally.

\subsection{Question of the Study}

The problem of the current study is determined by the following question:

How can educational activities based on image reading skills be designed to improve visual learning for children with learning disabilities?

\subsection{Objective of the Study}

The study aims to improve the visual learning of children with learning disabilities by practicing a series of educational activities based on image reading skills to provide them with educational experiences that contribute to their natural adaptation to life.

\subsection{Significance of the Study}

In our field contacts with ordinary children in general and children with special needs in particular, it shown that many children with learning disabilities are taught in our classes without paying attention to their natural situations. They are treated with the same treatment as the normal children, although these children suffer from many developmental and academic difficulties that do not enable them to complete the education process as should other normal children.

Many studies, such as (Fossett, 2004) has shown that learning difficulties are not due to auditory, visual or motor obstruction, etc., but they are manifested in the form of less actual performance than their aptitudes and abilities. These difficulties also require the use of a special method of dealing and education in order to help children reach the level of their ordinary mates of the same age, as demonstrated by the study of (Sword, 2005).

The difficulties faced by these children directly affect their ways of thinking and their awareness of everything that surrounds them, and they suffer from developmental difficulties, (perception, attention and focus). It means exposing the child to a problem in the process of cognition of the surrounding things, events and information. The current study attempts to 
handle the child's lack of understanding the meaning of the images surrounding him. This means, for example, that when a child looks at an image, he sees parts of it instead of seeing all of it. Or he may confuse background and image, so he can't focus without interfering with its background. Which makes him suffer from seeing parts without all, does not realize the concept or the overall meaning of the image. This affects his comprehension and his ability to see things and thus clearly affects his ability to learn especially visual and learning in general. It is clear from the summary of the previous studies that the problem of the current study did not take its share of research and experimentation at the local level especially with children with learning disabilities within the limits of the authors' knowledges. Therefore, the current study seeks to design educational activities based on the use of the image and give the child with learning difficulties reading skills to be able to acquire information in a simple and fun method, aiming to develop his visual learning skills that help him to live normally like his mates from regular children.

\section{Method}

The current study used the semi-experimental curriculum, where educational activities represent the independent variable (experimental), visual learning in the pre-school child is the dependent variable, and children with learning disabilities are divided into two groups (experimental and controller). The educational courses prepared by the authors based on the skills of reading the image are applied to the experimental group only, while the controller group is left to learn the traditional grade, then the distance measurement of the two groups and exit results and interpretations.

\subsection{Study Population and Sample}

The original community of this study is the first grade of primary schools in Alexandria, Egypt. A sample has been selected from (Eloubour Primary School) to be the main sample of this study. The age of children ranges from 7-8, and all of the respondents both (experimental and controller) have normal IQs (from school records). A number of children were identified in the survey sample (30) children from the (Future School in Alexandria), and their choice was taking care of the close to the social and economic level and the level of intelligence. They have been selected on the basis of the teacher's observations and the results of the tests, that the children's degree of achievement and attention in the classroom was below average. The aim of this sample is to legalize the study tools and identify children with visual learning skills.

\subsection{Basic Study Sample}

The basic study sample consists of (20) children (boy \& girl) with developmental learning disabilities, as well as a lack of reading skills. The children were divided into two groups (controller and experimental), each of which included (10) children who meet the conditions in terms of age, degree of intelligence and degree of difficulty.

\subsection{The Study Instrument}

The following study tools aimed to achieve the effectiveness of the educational activities practiced by the experimental group to develop and improve their visual learning. Therefore, the researcher used the following tools:

(a) Early Detection Scale for Developmental Learning Disabilities.

(b) Visual learning test for children of the study sample (prepared by the authors). 
(c) Educational activities based on the skills of reading the image of the child with learning disabilities in the first grade (Prepared by: authors). These activities consist of a set of phrases through which to recognize the developmental learning difficulties experienced by the child in the classroom. The teacher of the semester who spent a full school year with the child applies the list by answering the list terms of each child in the classroom separately. The child is given grades $(1,2,3,4)$ according to the sequence of response levels as they are in the list. The final sum is 80 marks. If the child has less than 48 marks $(60 \%$ of the total score of the list), he has knowledge learning difficulties.

\subsection{Visual learning test for children of the study sample 4.4.1 Test Objective}

The test aims to identify the basic dimensions of the child's reading skills, which the authors have adopted from previous studies, the theoretical framework and the various measures close to the current study. These four dimensions of the visual learning of the child (McCandliss , 2012), (Gurny, 2003) are as follows:

- The ability to recognize the visual form. (First dimension).

- The ability to analyze the visual form. (Second dimension).

- The ability to interpret visual form. (Third dimension).

- The ability to extract meanings from the visual form. (Fourth dimension).

\subsubsection{Test description}

The initial image of the test was prepared in the light of the knowledge available for the authors from previous studies, and the theoretical framework related to the subject of the present study and the identification of some of the tools and measures used by such studies (Gurny , 2008).

The authors prepared the test in its initial form of (29) pictures distributed on the four dimensions, mentioned in section-4.4.1, so that the first dimension included (8) pictures, the second dimension (8) pictures, the third dimension (6) pictures, and the fourth dimension (7) pictures. Then the test was presented in its initial form to a group of reviewers and then the number and content of some of the pictures presented were amended in accordance with the opinions of the reviewers. Where the test in its final form consists of (24) pictures distributed over the four dimensions mentioned above. Each dimension includes (6) pictures related to the dimension as follows:

(i) First dimension: The recognition of the visual form. It includes 6 pictures of different professions and personalities and the child has to identify the person in front of him - the picture may include more than one character and the surrounding objects.

(ii) Second dimension: The analysis of the visual form. It includes six different pictures (picture of a beach of the sea - a picture of a circus - a picture of an airport - a picture of a classroom - a picture of the zoo - a picture of a hospital room), on the child to say the parts of the whole picture. If the picture is composed of 10 components, the child must say at least 5 parts to take the degree of each picture, while noting the question in general should be: "What do you see in the picture?"

(iii) Third dimension: The interpretation of the visual form. It includes 6 pictures in which we present the child an integrated picture and then a separate image for each part of the picture. The child has to say why this is in the picture?; the child gives a reason for the existence and uses of things.

(iv) Fourth dimension: The extraction of the meanings from the visual form. It includes 6 pictures, in which the child is given separate pictures of parts of a whole portrait of a 
landscape. (For example, the picture of the airport is incomplete) and the child has to know the place as a whole and it means that he called the mental image of the airport format and say it.

\subsubsection{Validity of the test has been done as follows:}

The test was reviewed by ten reviewers in the field of education and early childhood curriculums. There was an agreement percentage $85 \%$ regarding the dimensions of the test.

\subsubsection{Validity of the internal consistency}

The verification of the internal consistency has been evaluated by calculating the correlation coefficient between each image and the dimension to which it belongs. This is illustrated in the following table: (Walpole, 1998).

Table (1) The value of the correlation coefficients at level of significance (0.01)

\begin{tabular}{|c|c|c|c|c|c|c|c|}
\hline $\begin{array}{l}\text { First } \\
\text { dimensio } \\
\mathrm{n}\end{array}$ & $\begin{array}{l}\text { Coefficie } \\
\mathrm{nt} \text { of } \\
\text { correlatio } \\
\mathrm{n}\end{array}$ & $\begin{array}{l}\text { Second } \\
\text { dimensio } \\
\mathrm{n}\end{array}$ & $\begin{array}{l}\text { Coefficie } \\
\mathrm{nt} \text { of } \\
\text { correlatio } \\
\mathrm{n}\end{array}$ & $\begin{array}{l}\text { Third } \\
\text { dimensio } \\
\mathrm{n}\end{array}$ & $\begin{array}{l}\text { Coefficie } \\
\text { nt of } \\
\text { correlatio } \\
n\end{array}$ & $\begin{array}{l}\text { Fourth } \\
\text { dimensio } \\
\mathrm{n}\end{array}$ & $\begin{array}{l}\text { Coefficie } \\
\text { nt of } \\
\text { correlatio } \\
n\end{array}$ \\
\hline $\begin{array}{l}\text { First } \\
\text { picture } \\
\text { (a } \\
\text { teacher) }\end{array}$ & 0.824 & $\begin{array}{l}\text { The } \\
\text { image of } \\
\text { the class }\end{array}$ & 0.758 & $\begin{array}{l}\text { The } \\
\text { image of } \\
\text { the class }\end{array}$ & 0.636 & $\begin{array}{l}\text { The } \\
\text { image of } \\
\text { the class }\end{array}$ & 0.740 \\
\hline $\begin{array}{l}\text { second } \\
\text { picture } \\
\text { (a diver) }\end{array}$ & 0.870 & $\begin{array}{l}\text { The } \\
\text { image of } \\
\text { the sea } \\
\text { beach }\end{array}$ & 0.835 & $\begin{array}{l}\text { The } \\
\text { image of } \\
\text { the sea } \\
\text { beach }\end{array}$ & 0.687 & $\begin{array}{l}\text { The } \\
\text { image of } \\
\text { the sea } \\
\text { beach }\end{array}$ & 0.823 \\
\hline $\begin{array}{l}\text { third } \\
\text { picture } \\
\text { (a } \\
\text { doctor) }\end{array}$ & 0.783 & $\begin{array}{l}\text { The } \\
\text { image of } \\
\text { hospital } \\
\text { room }\end{array}$ & 0.860 & $\begin{array}{l}\text { The } \\
\text { image of } \\
\text { hospital } \\
\text { room }\end{array}$ & 0.628 & $\begin{array}{l}\text { The } \\
\text { image of } \\
\text { hospital } \\
\text { room }\end{array}$ & 0.795 \\
\hline $\begin{array}{l}\text { fourth } \\
\text { picture } \\
\text { (a } \\
\text { gardner) }\end{array}$ & 0.787 & $\begin{array}{l}\text { The } \\
\text { image of } \\
\text { the zoo }\end{array}$ & 0.801 & $\begin{array}{l}\text { The } \\
\text { image of } \\
\text { the zoo }\end{array}$ & 0.701 & $\begin{array}{l}\text { The } \\
\text { image of } \\
\text { the zoo }\end{array}$ & 0.671 \\
\hline $\begin{array}{l}\text { fifth } \\
\text { picture } \\
\text { (a } \\
\text { clown) }\end{array}$ & 0.773 & $\begin{array}{l}\text { The } \\
\text { image of } \\
\text { the } \\
\text { circus }\end{array}$ & 0.823 & $\begin{array}{l}\text { The } \\
\text { image of } \\
\text { the } \\
\text { circus }\end{array}$ & 0.727 & $\begin{array}{l}\text { The } \\
\text { image of } \\
\text { the } \\
\text { circus }\end{array}$ & 0.803 \\
\hline $\begin{array}{l}\text { sixth } \\
\text { picture } \\
\text { (a pilot) }\end{array}$ & 0.820 & $\begin{array}{l}\text { The } \\
\text { image of } \\
\text { the } \\
\text { airport }\end{array}$ & 0.853 & $\begin{array}{l}\text { The } \\
\text { image of } \\
\text { the } \\
\text { airport }\end{array}$ & 0.762 & $\begin{array}{l}\text { The } \\
\text { image of } \\
\text { the } \\
\text { airport }\end{array}$ & 0.756 \\
\hline
\end{tabular}

It is clear from the previous table that the correlation coefficients between the degrees of each picture and the total score of the dimension are greater than the table value at the level of (0.01), which is $(0.402)$, which means that there is consistency between each image and the 
dimension to which it belongs. The correlation coefficient between the degree of each dimension and the total test score has been also calculated as shown in the following table:

Table (2) The coefficient of correlation between the degree of each dimension and the total degree of the test

\begin{tabular}{|c|c|c|}
\hline Serial & Dimension & $\begin{array}{c}\text { The coefficient of } \\
\text { correlation }\end{array}$ \\
\hline 1 & $\begin{array}{c}\text { First } \\
\text { dimension }\end{array}$ & 0.578 \\
\hline 2 & $\begin{array}{c}\text { Second } \\
\text { dimension }\end{array}$ & 0.487 \\
\hline 3 & $\begin{array}{c}\text { Third } \\
\text { dimension }\end{array}$ & 0.372 \\
\hline 4 & $\begin{array}{c}\text { Fourth } \\
\text { dimension }\end{array}$ & 0.579 \\
\hline
\end{tabular}

\subsubsection{Stability of the test}

The stability of the test is evaluated by exam repetition (Walpole,1998). The retest method has been re-applied by re-applying the measurement by an interval of two-weeks. The correlation coefficient was $(0.933)$ while the stability coefficient is $(0.946)$. The stability was also calculated on the sample using the split - half method and its value was (0.944), using "Pearson coefficient" (Walpole,1998).

\section{Educational activities based on the skills of reading the image of the child with learning disabilities in the first grade}

Activities are based on image reading skills - aiming to improve the performance of children in reading and understanding the image, in order to develop some improvement of their visual learning, which is reflected in their learning of educational experiences target at children with learning difficulties in primary education.

\subsection{Objective of the activities}

Designed activities aim to develop and raise awareness of children about the importance of the images presented to them both in school curricula and in life around them, and the ability to read correctly, which contribute to the development of their attention and awareness and support their visual learning (Ware, 2008), (McCandliss m, 2012), (Williams, 2003) and (Saleh, 2016). The activities were presented to (20) professors of psychology and children's curricula for the arbitration in terms of objectives, importance, program content and time of implementation. As well as its relevance to the sample and the techniques used and teaching aids used. Upon their views, the number of activities was adjusted to be three activities per day, and each activity lasted no more than 40 minutes. The application lasted two and a half months, (3) days a week and two hours a day, so that the time of the activity does not exceed 40 minutes. 


\section{Results and Discussion}

\subsection{Study Hypothesis}

The imposition of the study states that "there are statistically significant differences between the experimental and the controller group average scores" in order to test the assessment of visual thinking of children after the activities have been applied to the experimental group. To test the validity of this hypothesis, three statistical methods were used: Mann-Whitney (M), Wilcoxon (W) and (Z) (Walpole, 1998). The following tables present the results of this hypothesis.

Table (3) The values of (M), (W), (Z) and their significance for the difference between the controller and the experimental groups in the post-test scale of the performance rate on the visual thinking assessment of children (first dimension).

\begin{tabular}{|c|c|c|c|c|c|c|c|c|}
\hline The first & Contro & & Experin & ntal & Valu & Valu & Valu & \\
\hline $\begin{array}{l}\text { The skill } \\
\text { to } \\
\text { recognize } \\
\text { the visual } \\
\text { form }\end{array}$ & $\begin{array}{l}\text { Avera } \\
\text { ge } \\
\text { grades }\end{array}$ & $\begin{array}{l}\text { Sum } \\
\text { of } \\
\text { grad } \\
\text { es }\end{array}$ & $\begin{array}{l}\text { Averag } \\
\text { e grade }\end{array}$ & $\begin{array}{l}\text { Sum } \\
\text { of } \\
\text { grad } \\
\text { es }\end{array}$ & (M) & (W) & $(Z)$ & nce \\
\hline $\begin{array}{l}\text { First } \\
\text { image }\end{array}$ & 6.5 & 65 & 14.5 & $\begin{array}{l}145 . \\
0\end{array}$ & 10.0 & 65.0 & $\begin{array}{l}3.55 \\
9\end{array}$ & 0.01 \\
\hline $\begin{array}{l}\text { second } \\
\text { image }\end{array}$ & 5.5 & 55 & 15.5 & $\begin{array}{l}155 . \\
0\end{array}$ & 0.0 & 55.0 & $\begin{array}{l}4.25 \\
9\end{array}$ & 0.01 \\
\hline $\begin{array}{l}\text { Third } \\
\text { image }\end{array}$ & 6.5 & 65 & 14.5 & $\begin{array}{l}145 . \\
0\end{array}$ & 10.0 & 15.0 & 3.87 & 0.01 \\
\hline $\begin{array}{l}\text { Forth } \\
\text { image }\end{array}$ & 5.5 & 55 & 15.5 & $\begin{array}{l}155 . \\
0\end{array}$ & 0.0 & 55.0 & $\begin{array}{l}4.25 \\
9\end{array}$ & 0.01 \\
\hline $\begin{array}{l}\text { Fifth } \\
\text { image }\end{array}$ & 6.5 & 65 & 14.5 & $\begin{array}{l}145 . \\
0\end{array}$ & 15.0 & 65.0 & $\begin{array}{l}3.18 \\
7 \\
\end{array}$ & 0.01 \\
\hline $\begin{array}{l}\text { Sixth } \\
\text { image }\end{array}$ & 6.5 & 65 & 14.5 & $\begin{array}{l}145 . \\
0\end{array}$ & 10.0 & 65.0 & $\begin{array}{l}3.18 \\
7\end{array}$ & 0.01 \\
\hline
\end{tabular}

Table (4) The value of $(M),(W),(Z)$ for the difference between the mean scores of the controller and experimental groups in the post-test scale to evaluate the visual thinking of children (second dimension).

\begin{tabular}{|l|l|l|l|l|l|l|l|l|}
\hline $\begin{array}{l}\text { The second } \\
\text { dimension }\end{array}$ & \multicolumn{2}{|l|}{ Controller } & \multicolumn{2}{|l|}{ Experimental } & $\begin{array}{l}\text { Valu } \\
\text { e }\end{array}$ & $\begin{array}{l}\text { Valu } \\
\text { e }\end{array}$ & $\begin{array}{l}\text { Valu } \\
\text { e } \\
\text { (Z) }\end{array}$ & $\begin{array}{l}\text { Significa } \\
\text { nce }\end{array}$ \\
\hline $\begin{array}{l}\text { Level of } \\
\text { analysis of } \\
\text { visual form }\end{array}$ & $\begin{array}{l}\text { Avera } \\
\text { ge } \\
\text { grade } \\
\text { s }\end{array}$ & $\begin{array}{l}\text { Sum } \\
\text { of } \\
\text { grades }\end{array}$ & $\begin{array}{l}\text { Avera } \\
\text { ge } \\
\text { grade }\end{array}$ & $\begin{array}{l}\text { Sum } \\
\text { of } \\
\text { grades }\end{array}$ & (M) & (W) & & \\
\hline First image & 6 & 60 & 15 & 150.0 & 5.0 & 10.0 & $\begin{array}{l}3.94 \\
3\end{array}$ & 0.01 \\
\hline
\end{tabular}




\begin{tabular}{|l|l|l|l|l|l|l|l|l|}
\hline $\begin{array}{l}\text { second } \\
\text { image }\end{array}$ & 6.5 & 65 & 14.5 & 145.0 & 10.0 & 15.0 & $\begin{array}{l}3.48 \\
7\end{array}$ & 0.01 \\
\hline Third image & 8 & 80 & 13 & 130.0 & 25.0 & 80.0 & $\begin{array}{l}2.51 \\
7\end{array}$ & 0.01 \\
\hline Forth image & 5.5 & 55 & 15.5 & 155.0 & 0.0 & 55.0 & $\begin{array}{l}4.35 \\
9\end{array}$ & 0.01 \\
\hline Fifth image & 7 & 70 & 14 & 140.0 & 15.0 & 70.0 & $\begin{array}{l}2.19 \\
9\end{array}$ & 0.01 \\
\hline Sixth image & 6 & 60 & 15 & 150.0 & 5.0 & 60.0 & $\begin{array}{l}2.94 \\
2\end{array}$ & 0.01 \\
\hline
\end{tabular}

Table (5) The value of (M), (W), (Z) for the difference between the mean scores of the controller and experimental groups in the post-test scale for the assessment of children's visual thinking. (third dimension).

\begin{tabular}{|c|c|c|c|c|c|c|c|c|}
\hline \multirow{2}{*}{$\begin{array}{l}\text { The third } \\
\text { dimension } \\
\text { Level of } \\
\text { interpretati } \\
\text { on of } \\
\text { visual } \\
\text { form }\end{array}$} & \multicolumn{2}{|c|}{ Controller } & \multicolumn{2}{|c|}{ Experimental } & \multirow{2}{*}{$\begin{array}{l}\text { Valu } \\
\mathrm{e}^{-} \\
\text {(M) }\end{array}$} & \multirow{2}{*}{$\begin{array}{l}\text { Valu } \\
\mathrm{e}^{-} \\
(\mathrm{W})\end{array}$} & \multirow{2}{*}{$\begin{array}{l}\text { Valu } \\
\mathrm{e}^{(Z)}\end{array}$} & \multirow{2}{*}{$\begin{array}{l}\text { Significa } \\
\text { nce }\end{array}$} \\
\hline & $\begin{array}{l}\text { Avera } \\
\text { ge } \\
\text { grades }\end{array}$ & $\begin{array}{l}\text { Sum } \\
\text { of } \\
\text { grade } \\
\text { S }\end{array}$ & $\begin{array}{l}\text { Avera } \\
\text { ge } \\
\text { grade }\end{array}$ & $\begin{array}{l}\text { Sum } \\
\text { of } \\
\text { grades }\end{array}$ & & & & \\
\hline $\begin{array}{l}\text { First } \\
\text { image }\end{array}$ & 7.5 & 75 & 12.5 & 125.0 & 20.0 & 75.0 & $\begin{array}{l}2.61 \\
5 \\
\end{array}$ & 0.01 \\
\hline $\begin{array}{l}\text { second } \\
\text { image }\end{array}$ & 7 & 70 & 14 & 140.0 & 15.0 & 70.0 & $\begin{array}{l}3.19 \\
9\end{array}$ & 0.01 \\
\hline $\begin{array}{l}\text { Third } \\
\text { image }\end{array}$ & 6 & 60 & 15 & 150.0 & 5.0 & 60.0 & $\begin{array}{l}3.94 \\
3\end{array}$ & 0.01 \\
\hline $\begin{array}{l}\text { Forth } \\
\text { image }\end{array}$ & 6.5 & 65 & 14.5 & 145.0 & 10.0 & 65.0 & $\begin{array}{l}3.48 \\
7 \\
\end{array}$ & 0.01 \\
\hline $\begin{array}{l}\text { Fifth } \\
\text { image }\end{array}$ & 6.5 & 65 & 14.5 & 145.0 & 10.0 & 65.0 & $\begin{array}{l}3.48 \\
7\end{array}$ & 0.01 \\
\hline $\begin{array}{l}\text { Sixth } \\
\text { image }\end{array}$ & 6.5 & 65 & 14.5 & 145.0 & 10.0 & 65.0 & $\begin{array}{l}3.48 \\
7\end{array}$ & 0.01 \\
\hline
\end{tabular}

Table (6) The value of (M), (W), (Z) for the difference between the mean scores of the control and experimental groups in the pre-test scale to evaluate the visual thinking of children (fourth dimension).

\begin{tabular}{|l|l|l|l|l|l|l|l|l|}
\hline $\begin{array}{l}\text { The fourth } \\
\text { dimension }\end{array}$ & \multicolumn{2}{|l|}{ Controller } & \multicolumn{2}{l|}{ Experimental } & $\begin{array}{l}\text { Valu } \\
\text { e }\end{array}$ & $\begin{array}{l}\text { Valu } \\
\text { e }\end{array}$ & $\begin{array}{l}\text { Valu } \\
\text { e }\end{array}$ & $\begin{array}{l}\text { Significa } \\
\text { nce }\end{array}$ \\
\hline $\begin{array}{l}\text { Level of } \\
\text { interpretati } \\
\text { on of } \\
\text { visual } \\
\text { form }\end{array}$ & $\begin{array}{l}\text { Avera } \\
\text { ge } \\
\text { grades }\end{array}$ & $\begin{array}{l}\text { Sum } \\
\text { of } \\
\text { grade } \\
\text { s }\end{array}$ & $\begin{array}{l}\text { Avera } \\
\text { ge } \\
\text { grade }\end{array}$ & $\begin{array}{l}\text { Sum } \\
\text { of } \\
\text { grades }\end{array}$ & (M) & (W) & & \\
\hline First & 7 & 70 & 14 & 140.0 & 15.0 & 70.0 & 3.19 & 0.01 \\
\hline
\end{tabular}




\begin{tabular}{|l|l|l|l|l|l|l|l|l|}
\hline image & & & & & & & $9-$ & \\
\hline $\begin{array}{l}\text { second } \\
\text { image }\end{array}$ & 6 & 60 & 15 & 150.0 & 5.0 & 60.0 & $\begin{array}{l}3.94 \\
2-\end{array}$ & 0.01 \\
\hline $\begin{array}{l}\text { Third } \\
\text { image }\end{array}$ & 7 & 70 & 14 & 140.0 & 15.0 & 70.0 & $\begin{array}{l}3.06 \\
7-\end{array}$ & 0.01 \\
\hline $\begin{array}{l}\text { Forth } \\
\text { image }\end{array}$ & 5.5 & 55 & 15.5 & 155.0 & 0.0 & 55.0 & $\begin{array}{l}4.35 \\
9-\end{array}$ & 0.01 \\
\hline $\begin{array}{l}\text { Fifth } \\
\text { image }\end{array}$ & 7 & 70 & 14 & 140.0 & 15.0 & 70.0 & $\begin{array}{l}3.06 \\
7-\end{array}$ & 0.01 \\
\hline $\begin{array}{l}\text { Sixth } \\
\text { image }\end{array}$ & 6 & 60 & 15 & 150.0 & 5.0 & 60.0 & $\begin{array}{l}2.94 \\
3-\end{array}$ & 0.01 \\
\hline
\end{tabular}

Tables (3), (4), (5) and (6) show that the differences between the mean scores of the two groups, significance at the mean of 0.01 , is in favor off the experimental group.

\subsection{Discussion}

The results showed that there were statistically significant differences between the experimental and control group scores in order to test the assessment of children's visual thinking after applying the activities in favor of the experimental group, and this is what validates the imposition of this study. The results indicate the effectiveness of the activities that were developed in the skills of reading the image to develop visual learning skills for children with learning difficulties in kindergarten. These results are in agreement with most of the studies on this subject, such as (Moran \& Tegano, 2005), (Mcleann \& Gorman , 2006), (Ware, 2008) and (Manning, 2004). (Jenkins, 2000), (Valiquette, Gérin-Lajoie \& Sutton, 2006), (Noël, 2015), (Mohd-Nor et al, 2012), (Tasuc, 2010)

The results also emphasize the importance of the image and its success and impact on the development of visual learning, as agreed by (Colin, 2008), (Mc Candliss , 2012), Williams (2003) show that the visual learning depends on the image by up to $90 \%$ and it becomes a source of knowledge of the child who turns it into a mental image which can be retained to be retrieved when needed.

Thus, visual learning was supported for the study sample, which is reflected in the positive impact on the acquisition of educational experiences and effective life communication.

\section{Suggestions and Recommendations}

1- The need to pay attention to the quality of programs offered to the ordinary child and children with special needs.

2- Attention to the need to provide image-related programs and to treat the child properly.

3- Attention to the images in the textbooks at all levels of education, because they have an effective impact in the process of teaching and learning.

4- The need to provide training programs to develop visual thinking skills for children with learning difficulties because they are in real need of these trainings.

\section{References}

[1] Bedoin, D., Scelles, R .(2015). Qualitative research interviews of children with communication disorders: methodological implications, European Journal of Special Needs Education, 30:4, 474-489. 
[2] McCandliss B. D. (2012). Helping dyslexic children attend to letters within visual word forms. Proceedings of the National Academy of Sciences of the United States of America, 109(28), 11064-11065.

[3] Callow, J. (2004). Talking About Visual Texts with Students. Reading online. 6 (8), 1-16. Retrieved

from:https://www.researchgate.net/profile/Jon_Callow/publication/281069609 Talki ng about visual texts with students/links/55d3d70b08ae0b8f3ef93437.pdf

[4] Ware, C. (2008). Visual thinking for design. Burlington, MA: Ware Kaufmann.

[5] Ottino, F. A. (2011). The persuasive writing skills of language learning disabled and typically developing college students. Master of science. The William Paterson University of New Jersey, Available from ProQuest Dissertations \& Theses Global. (749759263).

Retrieved from https://search.proquest.com/docview/749759263?accountid=27804

[6] Fossett, B .(2004). Visual Support Strategies for Literacy Development. SEA Crosscurrents Magazine, 23-32. Retrieved from: https://bctf.ca/diversity/resourceinventory/crosscurrents/Spring04pp23-32.pdf

[7] Gurny, H. G. (2003). High school students' performance on vandenberg's mental rotations test: Art ability, gender, activities, academic performance, strategies, and ease of taking the test Available from ERIC. (62166902; ED479372). Retrieved from: https://search.proquest.com/docview/62166902? accountid=27804

[8] Lecas, J., Mazaud, A., Reibel, E., \& Rey, A. (2011). Using visual strategies to support verbal comprehension in an adolescent with down syndrome. Child Language Teaching and Therapy, 27(1), 84-96. doi:http://dx.doi.org/10.1177/0265659010371564

[9] Ganz, J. B., \& Flores, M. M. (2008). Effects of the use of visual strategies in play groups for children with autism spectrum disorders and their peers. Journal of Autism and Developmental Disorders, 38(5), 926-940. Retrieved from https://search.proquest.com/docview/69393847?accountid=27804

[10]Sword, L. (2005). The Power of Visual Thinking. Gifted and Creative. Services Australia. Lowenthal, Retrieved from: http://www.starjump.com.au/media/Papers $\% 20 \% 20$ Articles/The $\% 20$ Power $\% 20$ of $\% 2$ 0Visual\%20Thinking.pdf

[11]Saleh, M. (2014). The production of educational materials for children. Knowledge House for publishing, Alexandria, Egypt, 134

[12]Manning, M. (2004). A world of words. Teaching Pre-K-8, 34(7), 78-79.

[13]Moran, M. J., \& Tegano, D. W. (2005). Moving toward visual literacy: Photography as a language of teacher inquiry. Early Childhood Research \& Practice, 7(1), 1-21. Retrieved from https://search.proquest.com/docview/1871587977?accountid=27804

[14]Mcleann D. \& Gorman, L. (2006). Media and Society in the Twentieth Century: A Historical Introduction, Malden, MA: Blackwell Publishing.

[15]Moljord, G. (2018). Curriculum research for students with intellectual disabilities: A content-analytic review. European Journal of Special Needs Education, 33(5), 646659. doi:http://dx.doi.org/10.1080/08856257.2017.1408222

[16]Schickedanz, J. (2003). Engaging Pre School in Code Learning: Some Thoughts About Pre- School Teachers. Concerns in D. Barone and Marrow (Eds.) Practices,121- 139. New York: Guilford 
[17]Matthew J. S (2016) Must inclusion be special? Rethinking educational support within a community of provision, European Journal of Special Needs Education, 31:2, 295-296, DOI: 10.1080/08856257.2015.1134949

[18]Walpole. R. (1998). Introduction to Statistics (2nd ed). Macmillan Publishing Co, Inc. New York, 148-149

[19]Williams, K (2003). Understanding Media Theory. New York : Distributed in U.S.A. by Oxford University Press

[20]Jenkins, P. S. (2000). A case study of metacognitive strategy use relative to the use of the visual image concept mapping software, "Inspiration", by college students with learning disabilities (Order No. 9998366). Available from ProQuest Dissertations \& Theses Global. (304640757). Retrieved from https://search.proquest.com/docview/304640757?accountid=27804

[21]Valiquette, C., Gérin-Lajoie Anne-Marie, \& Sutton, A. (2006). A visual graphic tool to support the production of simple sentence structuresin a student with learning disability. Child Language Teaching and Therapy, 22(2), 219-240. doi:http://dx.doi.org/10.1191/0265659006ct302oa

[22]Noël, G. (2015). Designing a visual tool to interview people with communication disabilities: A user-centered approach. Visible Language, 49(1), 63-79. Retrieved from: http://search.proquest.com/docview/1678028253?accountid=27804

[23]Mohd-Nor Muzaliha, Nurhamiza, B., Hussein, A., Abdul-Rani Norabibas, MohdHisham-Basrun, J., Sarimah, A., Shatriah, I. (2012). Visual acuity and visual skills in malaysian children with learning disabilities. Clinical Ophthalmology, 6, 1527-1533. doi:http://dx.doi.org/10.2147/OPTH.S33270

[24]Tasuc and info lounge announce 'TASUC SCHEDULE' sound \& visual tool for children with developmental disabilities - for iPhone, iPod touch and iPad. (2010, Nov 29). JCN Newswire - Japan Corporate News Network Retrieved from https://search.proquest.com/docview/814445341?accountid=27804 